\title{
PREDICTING AUDIT DELAY OF CONSUMER GOODS COMPANIES LISTED IN INDONESIA STOCK EXCHANGE
}

\author{
Akhmad Rif'at, Wiwit Apit Sulistyowati \\ University of Swadaya Gunung Jati Cirebon \\ rokhman@gmail.com
}

\begin{abstract}
This research aims to analyze the influence of profitability, solvability, and the audit committee partially against the audit delay on the company's industrial sector manufacturing consumer goods listed on the Indonesia stock exchange for the period 2014 up to 2016. The selection of the sample in this research was done using a purposive sampling method and acquired 32 companies as samples. The data used are of audited financial reporting of the sample companies published through the site www.idx.co.id and the official website of each company. Data analysis method used in this research is by using multiple linear regression. The results of this research show that profitability, solvability, and the audit committee have no effect on audit delay.
\end{abstract}

Keywords: Profitability; solvability; the audit committee; audit delay

\section{INTRODUCTION}

The timeliness of the publication of the audited financial report of is very important especially for the public companies that use the capital market as one of the sources of their funding. Submission of financial statements to the public and to the Financial Services Authority (OJK) also depends on the timeliness of the auditor in completing the audit work. However, the submission of the annual report of the company often vary. This is because the Auditors also need time to gather evidence supporting his opinions were competent. The length of time the completion of the audit, this can affect the timeliness of the information published.

The phenomenon of the length of time the completion of the audit this audit was called the delay or other terms i.e. audit report lag. According to
Ashton et al. (1997) defines the audit delay as the length of time the completion of the audits carried out by auditors as measured from the year closed the company's books until the date of the publication of the audit report. Thus, the longer the audit delay that occurred at the company, it will be the longer the auditor and finish the audit job. This will have an impact on the delivery financial report to the public.

In Indonesia, the rules regarding the timing of financial reporting regulated by Bapepam and LK (capital market Supervisory Agency and the financial institutions) in the decision of the Chairman of Bapepam and LK number: KEP-346/BL/2011 about the submission of periodic financial reports or corporate issuers the public which states that: "The 
mandatory annual financial reports submitted to Bapepam and LK and announced to the community at the latest at the end of the third month after the date of the annual financial report". In the year 2016, Bapepam and LK number: KEP-346/BL/2011 about the submission of periodic financial reports of issuers or public companies has been replaced by the regulation of the financial services authority no. 29/POJK. 04/2016 annual reports of issuers or public company mention that: "Issuers or Public companies are obliged to submit annual reports to the financial services authority at the latest by the end of the fourth month after the fiscal year ends. When public companies that violate rules the Financial Services Authority (OJK), including parties that led to the breach of that provision, it will be subject to administrative sanction in the form of a written warning, fines, namely the obligation to pay a certain amount of money, restrictions on business activities, freezing of business activities, business license revocation, cancellation of approval, and cancellation of registration".

Many factors can potentially affect the audit delay on the company. Profitability is one indicator of the success of the company in generating profit. Research Putri (2015) and Angruningrum \& Wirakusuma (2013) argued that profitability had no effect against the audit delay. In contrast to the results of research conducted by Saemargani \& Mustikawati (2015) and Trisnawati \& Charistine (2008) which found that the profitability of the company's effect on the audit delay.

When a company has high profitability means management performance is considered good and it is good news that should be immediately communicated to the stakeholders, so the good news it can improve the confidence of investors and potential investors to the company. This may mean that the company has good internal controls in order to achieve the objectives of the company so that the auditor is not so difficult and does not require a long time in carrying out auditing for collecting evidence Audit over the company's transactions, then the field auditor work time will be faster.

Other factors that affect estimated is solvability. According to research conducted Saemargani\&Mustikawati (2015) and Trisnawati \& Charistine (2008) found that their solvability has no effect on the audit delay. While according to Ningsih\&Widhiyani (2015) and Apriyani (2015) argues that the positive effect their solvability against audit delay. This shows that when the proportion of debt owned by the company is high, then the company should confirm the acquisition debt to related parties (debtholder). When the auditor shall audit the accounts of the debt, then this will take a long time for the Auditors having to seek the cause of the high proportion of such debt. Therefore, this will result in delays in the preparation of the audit report and indicate the occurrence of an increasingly long delay audit.

Other internal factors that can affect an estimated delay is auditing the audit committee. Research Ningsih \& Widhiyani (2015) and Angruningrum \& Wirakusuma (2013) found that the number of the existing audit committee within the company have no effect against the audit delay. Contrary to research done Haryani \& Wiratmaja (2014), which argued that the audit committee impact on auditing delay as well as on research Apriyani (2015) which found that audit committee negatively influence on audit delay. This shows that the addition of the audit committee members will tend to increase the supervisory process in the preparation of the financial statements of the company so that the resulting 
financial reports to be more in accordance with generally accepted standards. This means the time needed by the auditors in carrying out job audit be shorter.

\section{LITERATURE REVIEW}

According to Jensen and Meckling, (1976:4) describes agency relationship as a contract under which one or more persons (the principal) engage another person (the agent) to perform some service on their behalf which involves delegating some decision making authority to the agent. Agency theory is used to assist the audit committee in understanding the conflicts of interest that arise between owners and management, so hopefully not happen to cheat in the preparation of financial statements that can engender time lag of audit a prolonged delay.

Signal theory was first developed by Ross (1977), which States that: "In developing the theory of signal based on the existence of information asymmetry between information management (wellinformed) and information from shareholders (poo informed). The theory is based on the thought of under management will provide information to investors or shareholders when it gets good information related to companies such as an increase in the value of the company.

Companies that have high profitability has a negative relationship toward the audit delay due to the company's management considers that it is good news that should soon be published to stakeholders in order to increase the value of the audit firm and the resulting delay will be briefer. While companies that have low profitability then his report will contain bad news, and tend not to provide timely financial reports because of the need to find the source of the cause of the loss and will cause the audit delay getting longer.

Research conducted Saemargani \& Mustikawati (2015) and Amani \& Waluyo (2016) gets results that the profitability of the companies has a significant influence towards the audit delay. This is in line with research conducted by Trisnawati \& Charistine (2008). Based on the description, proposed the hypothesis in this study is:

H1: Profitability effect negatively to the audit delay

When the company has a lot of debt then the resulting solvability ratio will be high. The higher the ratio of solvability, then auditor will tend to take more in the audit of the financial statements of the company or of the audit delay happens will the long, so that indicates the delay in publishing the report audited to the public and make this as bad news and can lose the trust of the investors to the company. This is in accordance with the theory of signals that mention that the management will provide information to investors or shareholders when it gets good information related to companies such as debt ratio or a low solvability.

Research has done by Putri (2015) and Apriyani (2015) find the results that the positive effect their solvability against audit delay. This is in line with research conducted by Ningsih \& Widhiyani (2014). Based on the description, proposed the hypothesis in this study is:

H2: Solvability effect positively to the audit delay

Agency theory used in this study to assist the audit committee in understanding the conflicts of interest that arise between owners and management, so hopefully not happen to cheat in the preparation of financial statements which may cause grace period the audit delay is prolonged.

Audit committee assists the Board of Commissioners the independent monitor 
and oversees the implementation and results of the audit of internal control resulting in good company. Research conducted Apriyani (2015) and Janartha $\&$ Suprasto (2016) gives the results of hypothesis testing that shows that the solvability impact on audit delay. This is in line with research conducted by Haryani \& Wiratmaja (2014). Based on the description, then the hypothesis presented by the researchers is:

H3: Audit Committee effect negatively to the audit delay

\section{RESEARCH METHOD}

This type of research is basic research, as a result of this research just to develop an existing theory. The selected population in this research is a company manufacturing industrial sector of consumer goods that are listed on the Indonesia stock exchange in the period 2014-2016. The criteria used in sampling is the industrial sector manufacturing company of consumer goods listed respectively in the Indonesia Stock Exchange for the period 2014-2016; publish financial statements audited consistently for 3 years in the Indonesia Stock Exchange and the company's official website in 20142016; publish their financial reports with a closing date of 31 December in the yearbook 2014-2016 and experiencing profit respectively in the year 20142016.

The following table is the measurement of variables:

Table 1. Variable Operationalization

\begin{tabular}{llc}
\hline \multicolumn{1}{c}{ Variable } & Measurement & Scale \\
\hline $\begin{array}{l}\text { Audit Delay } \\
(\mathrm{Y})\end{array}$ & $\begin{array}{l}\text { Audit Delay }=\text { closing date of financial statements }- \text { date of the audit } \\
\text { report }\end{array}$ & Ratio \\
\hline $\begin{array}{l}\text { Profitability } \\
(\mathrm{X} 1)\end{array}$ & $R O A=\frac{\text { Net Income }}{\text { Total Aset }}$ & Ratio \\
\hline $\begin{array}{l}\text { Solvability } \\
(\mathrm{X} 2)\end{array}$ & $D A R=\frac{\text { Total Liabilities }}{\text { Total Aset }}$ & Ratio \\
\hline & The proportion of Audit Comittee $=\frac{\text { Total Audit Comittee }}{\text { Total Board of Commisioner }} \times 100 \%$ & Ratio \\
\hline \multicolumn{2}{c}{ Source: Ashton, dkk (1987), Suparsada dan Putri (2017), Putri dan Asyik (2015), Haryani dan Wiratmaja (2014). }
\end{tabular}

Data analysis techniques

The study uses regression analysis to analyze the influence of profitability, solvability and the audit committee to the audit delay. A classic assumption test used includes test normality test, multicollinearity test, autocorrelation and heteroskedasticity test. Partial hypothesis test (test t) was used to test the influence of partially.

\section{RESULTS AND DISCUSSION}

\subsection{Results}

In this study, to test the residual normality is a non-parametric statistical test of Kolmogorov Smirnov (K-S). Based on the result shows that the value of the test statistic is of significance level and have a 0.091 Asymp. Sig (2tailed) of the variables as a whole amounted to 0.063 which that value greater than 0.05 and the data is 
normally distributed. Based on the autocorrelation test, the results of the count value and value table DurbinWatson has fulfilled the criteria of $\mathrm{du}<$ DW $<4$-du, namely $1,7264<1,844<$ 2,2736 . Then it can be concluded that there is no positive or negative correlation, or it can be concluded that there is no autocorrelation. Multicollinearity test shows that tolerance value each of variables is higher than 0,1 and VIF (Variance
Inflation Factor) each of variables is under 10 , so it can conclude there is no multicollinearity. The results of a test of heteroskedasticity by using Glejser test shows that the value of the count level o significance is happening on all the independent variables more than 0.05 . Based on the results of these tests, it can be concluded that there are no symptoms of heteroskedasticity regression models. The following is a table of the results of multiple linear regression analysis:

Table 2. Multiple Regression Test

\begin{tabular}{|c|c|}
\hline Description & Sig \\
\hline Profitability & 0,992 \\
\hline Solvability & 0,120 \\
\hline Audit committee & 0,089 \\
\hline
\end{tabular}

\subsection{Discussion \\ The effect of profitability on audit delay}

Based on the results, the significance level of profitability 0.992 or there was no influence of profitability on audit delay. It is supports research conducted by Putri \& Asyik (2015) and Angruningrum \& Wirakusuma (2013) are finding that profitability had no effect on audit delay but the results were not in line with Saemargani \& Mustikawati (2015) and Trisnawati \& Charistine (2008) which found that the profitability has effect on the audit delay. The majority of the company shows an increase in the ratio of profitability. The higher the level of profitability of the acquired company, then the company will further improve the control of assets which have not suffered losses so that the audit delay that occurs will be increasingly short. The increase in net profit this happened due to an increase in business operations that originate from the activities of the company's net sales. While the resolution time of the majority of the company's audit examined in 2014-2016 under the 90 and 120 days. This is in accordance with the provisions of the regulated by Bapepam-LK and OJK. Therefore, the value of which increased profitability does not affect the audit delay.

The effect of solvability on audit delay

Based on the results, the significance level of solvability 0.120 or there was no influence of solvability on audit delay. The results support the research conducted by Saemargani \& Mustikawati (2015) and Trisnawati \& Charistine (2008) which concluded that solvability has no effect on audit delay but were not in line with Ningsih \& Widhiyani (2015) and Apriyani (2015) which found that the solvability of the company has a positive effect on audit 
delay. Majority of the company showed a decrease in the level of solvability, the company then owned the majority of the company's owned assets not financed by debt. As such, the company will further improve the control of assets, so that it can manage its debt so that it can lowering the solvability ratio and this can reduce the audit delay.

\section{The effect of the audit committee on audit delay}

Based on the results shows the significance of audit committee is 0.089 or there was no influence of the audit committee on audit delay, thus the $\mathrm{H} 3$ was rejected. It is supports research conducted by Ningsih \& Widhiyani (2015) and Angruningrum \& Wirakusuma (2013) which found that solvability has no effect on audit delay but not in line with Haryani \& Wiratmaja (2014), which argued that the audit committee impact on auditing delay as well as on research Apriyani (2015) which found that the solvability of influential negatively against the audit delay. Majority of the company has fulfilled its obligations in accordance with Regulation No. 55/OJK POJK. $04 / 2015$ on the establishment and implementation of the guidelines of the audit committee states that public companies must form an audit committee by the Board of Commissioners of at least three (3) people members of independent Commissioners and outside parties issuers or public companies as well as chaired by an independent commissioner. That is, the more the number of members of the audit committee the audit delay that happens then will be increasingly short because of the audit committee have the auth as managing supervisor for internal auditors of companies that helps independent Commissioner in monitoring the planning and execution as well as the evaluation of the results of the audit. This can reduce the delay in the submission of financial reports to the public.

\section{CONCLUSIONS}

The results of this research show that profitability, solvability and audit committee have no effect against the audit delay. This is due to that with the majority of the companies increase profitability, decline in the value of the debt to total asset, indicating that the process of auditing the auditor performed faster. Therefore, this does not affect the time of completion of the audit (the audit delay).

The result of this research has an impact on the management of the company, which will enhance management control optimally towards asset management companies as well as increase surveillance against the implementation of auditing thus audit resolution time faster. With report audited it conveys to the public quickly, it does have an impact to the stakeholders especially investors in which investors will be getting quicker in decision-making towards funding the company, so the value of the company will be experience increased. Management will improve control of asset companies and improve the supervision of audit, so the resolution time the audit will more quickly and have an impact on the speed of publication audit reports to the public.

The limitations in the study are including sample company used in this study was limited to the industrial sector manufacturing company of consumer goods of the year 2014-2016. The independent variables that were used in this study only 3 variables, namely, profitability, solvability and audit committee.

Further studies expected to expand units of analysis, not only in the industrial sector of consumer goods but 
add other sectors outside the sector, so that the results can be generalized, add a longer observation period and add another variable that could affect the delay, such as the auditor's opinion, the

\section{REFERENCES}

Amani, Fauziah and Althaf Indarto Waluyo. 2016. The influence of size of Companies, the Profitability, the Audit Opinion, and Age of the company's response to the Audit Delay. Nominal journal $\mathrm{V}$ number 1. Yogyakarta State University accounting: $135-50$.

Angruningrum, Silvia and Made Gede Wirakusuma. 2013. The influence of Profitability, Leverage, Complexity of operations, reputation of the KAP and of the Audit Committee at Audit Delay. E-Journal of Accountancy University of Udayana. ISSN: 2302-8556 5 (2): $251-70$.

Apriyani, Nurul Nur. 2015. The influence of Solvability, Auditor's opinion, the size, and the Audit Committee's response to the Audit Delay. Journal of accounting and information technology system vol. 11:169 - 77 .

Ashton, Robert H, John J. Willingham, and Robert k. Elliott. 1987. Research Reports An Empirical Analysis of the Audit. Journal of Accounting Research 25 (2): 275 92.

Haryani, Jumaratul and I Dewa Nyoman Wiratmaja. 2014. The influence of the size of the company, the Audit Committee, the application of International Financial Reporting Standards, and Public Ownership On the Audit Delay. E-Journal of Accountancy University of Udayana. ISSN: 2302-8556 6 (1): $63-78$. type of industry, company size, and age the company.

Indonesia (2011). The decision of the Chairman of Bapepam and LK number: KEP-346/BL/2011 about the submission of Periodic Financial reports of Issuers or public companies. Jakarta: Minister of law and human rights.

Indonesia (2016). Regulation of the financial services authority no. 29/POJK. 04/2016 Annual Reports of Issuers or public companies. Jakarta: Minister of law and human rights.

IV, James c. Dyer, and Arthur j. McHugh. 1975. The Timeliness of the Australian Annual Report. Journal of Accounting Research 13 (2): 204.

Janartha, I Wayan Pawn and Bambang Suprasto h. 2016. Influence of the size of the company, the existence of the Audit Committee and Leverage against the Audit Delay. "E-Journal of Accountancy University of Udayana. ISSN: 2302-8556 16 (3): 2374 - 2406.

Jensen, Michael c. and William $h$. Meckling. 1976. Theory of The Firm: Electrical Behavior, Agency Costs And Ownership Structure. Journal of Financial Economics 3 (4): $305-60$.

Ningsih, I Gusti Ayu Puspita Sari and Ni Luh Sari Widhiyani. 2015. The influence of the size of the company, operating profit, Solvability, and Audit Committee at Audit Delay. E-Journal of Accountancy University Of 
Economics and Accounting Journal

Vol. 2, No. 1, January 2019

Udayana. ISSN: 2302-8556 12 (3): $481-95$.

Putri, Kiki Prasilya and Nur Fadjrih. 2015. Influence Profitability, Solvability, opinion Auditor, the size of the company, and the reputation of the Auditors Audit against Delay. Journal of Accounting Research and Science 4 (9): $1-15$.

Ross, Stephen a. 1977. The Determination of Financial Structure: The Incentive-Signalling Approach. The Bell Journal of Economics 8 (1): 23.

Saemargani, Mak Ingga and Rr. Mustikawati Wonderful. 2015. The influence of the company's Size, age, company Profitability, Solvability, the size of the HOOD, and the opinion of the Auditors Audit against Delay. Nominal journal IV (2): 1-15.

Trisnawati, and Estralita Charistine. 2008. The Audit Opinion, Influence Profitability, Solvability Ratio, and size of the hood Against the Audit Delay. Accounting Journal 8 (1): $107-26$.

www.idx.co.id.

www.sahamok.com. 